\title{
Persepsi Siswa Terhadap Keterampilan Mengajar Guru di SMK Negeri 1 Lembah Gumanti
}

Nola Safitri ${ }^{1}$, Sulastri ${ }^{2}$, Jasrial ${ }^{3}$, Nelfia $\mathrm{Adi}^{4}$

${ }_{1,2,3,4}$ Administrasi Pendidikan, Universitas Negeri Padang

Nola Safitri'1, e-mail: nolasafitri25@gmail.com

Sulastri² e-mail: sulastri_aip@fip.unp.ac.id

Jasrial ${ }^{3}$ e-mail: jas.rial@yahoo.com

Nelfia Adi ${ }^{4}$ e-mail: nelfiaadi@fip.ac.id

\begin{abstract}
This study is based on the results of the author's observations at SMK Negeri 1 Lembah Gumanti regarding Teacher Teaching Skills which are still not being implemented optimally. This study aims to obtain information about Student Perceptions of Teacher Teaching Skills at SMK Negeri 1 Lembah Gumanti from the indicators of opening lessons, explaining, asking questions, providing reinforcement, class management, and closing lessons. This study is descriptive with quantitative methods. The population of this study were 515 students of SMK Negeri 1 Lembah Gumanti class XI and XII in the Department of Communication, Hospitality, Culinary, Clothing, so the sample size was 89 respondents. Sampling in this study used the Stratified Propotional Random Sampling technique. The materials collected using a questionnaire with a Likert scale have been tested for validity and reliability. The average formula is used in processing the data in this study. The data show student responses regarding the skills of teachers from: (1) opening good category lessons with a value of 3.84; (2) describes the good category with a value of 3.84; (3) asking for a fairly good category with a score of 3.52 ; (4) provides a fairly good category reinforcement with a score of 3.46; (5) managing good category classes with a score of 3.73 ; (6) closing the lesson in the category of good enough with a score of 3.57. Overall Students' Perceptions of Teacher Teaching Skills at SMK Negeri 1 Lembah Gumanti were in a good category with a score of 3.66.
\end{abstract}

\begin{abstract}
Abstrak
Kajian ini didasari oleh hasil pengamatan penulis di SMK Negeri 1 Lembah Gumanti mengenai Keterampilan Mengajar Guru yang masih kurang terlaksana dengan optimal. Kajian ini bertujuan untuk mendapatkan informasi mengenai Persepsi Siswa terhadap Keterampilan Mengajar Guru di SMK Negeri 1 Lembah Gumanti dilihat dari indikator membuka pelajaran, mnjelaskan, bertanya, memberikan penguatan, pengelolaan kelas, dan menutup pelajaran. Kajian ini bersifat deskriptif dengan metode kuantitatif. Populasi kajian ini yaitu Siswa SMK Negeri 1 Lembah Gumanti kelas XI dan XII Jurusan Otkp, Perhotelan, Tata boga, Busana berjumlah 515 orang siswa maka besar sampel yang di ambil 89 responden. Penarikan sampel pada kajian ini memakai teknik Stratified Propotional Random Sampling. Bahan yang dikumpulkan menggunakan kuesioner dengan skala likert telah diuji coba validitas dan reliabilitasnya. Rumusan rata-rata digunakan dalam mengolah data pada kajian ini. Data menunjukan tanggapan siswa mengenai keterampilan guru dari: (1) membuka pelajaran kategori baik dengan nilai 3.84; (2) menjelaskan kategori baik dngan nilai 3.84; (3) bertanya kategori cukup baik dengan nilai 3.52; (4) memberikan penguatan kategori cukup baik dengan nilai 3.46; (5) mengelola kelas kategori baik dengan nilai 3.73; (6) menutup pelajaran kategori cuku baik dngan nilai 3.57. Secara keseluruhan Persepsi Siswa terhadap Keterampilan Mengajar Guru di SMK Negeri 1 Lembah Gumanti sudah kategori baik dengan nilai 3.66 .
\end{abstract}

Kata Kunci: Keterampilan Mengajar Guru, Siswa

How to Cite: Nola Safitri 1, Sulastri 2, Jasrial 3, Nelfia Adi 4, 2021. Persespi siswa terhadap keterampilan mengajar guru di SMK Negeri 1 Lembah Gumanti. Journal Educational Administrasi and Leadership, Vol (N): pp.XX-XX,DOI:10.24036/XXXXXXXXXX-X-XX 


\section{Pendahuluan}

Guru dituntut untuk terampil melakukan pembelajaran membuka, menutup pelajaran, mengelola kelas, mengadakan variasi, bertanya, memberikan penguatan, membimbing kelompok kecil, perorangan, menggunakan media pembelajaran dan penerapan metode pembelajaran. Keterampilan mengajar guru sangat penting dalam proses mengajar dan diperlukan juga guru dapat melakukan dan pelaksanaan berbagai strategi pengkajian dalam penyelenggaraan sistem sehingga penataran mampu berlangsung dengan baik dan tepat. Keterampilan mengajar guru yang mengaplikasikan dengn baik akan diikuti dengan proses serta hasil yng baik pula. Dan hal itu guru harus dituntut untuk memiliki keterampilan mengajar yang berkaitan dengan pendidikan.

Dari penjelasan diatas dapat terlihat bahwa dalam dunia pendidikan seorang guru harus mampu dan profesional terhadap pelaksanaan keterampilan mengajar. Guru Tidak saja mengajar guru harus mampu melaksanakan keterampilan mengajar dan terampil pula dalam mentransfer ilmunya.

Kompetensi mengajar guru mewujudkan keahlian profesional yang matang, sebagai penggabungan dari berbagai keterampilan guru secara utuh, Syaripuddin (2011).

Adapun beberapa indikator keterampilan mengajar guru yaitu:

Keterampilan membuka pelajaran yaitu satu aktivitas yang membuat guru untuk membentuk kesiapan psikis dan menarik hati minat siswa cara optimum, supaya berusaha memfokuskan pribadi seutuhnya pada pengetahuan yng disampaikan, Mulyasa (2011). Keterampilan menjelaskan ialah penyampaian arahan secara verbal yang dikelola secara sistematis untuk menyatakan seadanya ikatan antara satu dengan lain, Asril (2011). Keterampilan bertanya sangat berarti apabila dihubungkan dengan anggapan menyatakan "berpendapat sendiri adalah bertanya, Asril (2011) Keterampilan memberikan penguatan yaitu jawaban tentang watak nyata yang meningkatnya kembali watak tersebut, Asril (2011). Pengelolaan kelas ialah kemampuan untuk mewujudkan, mengusahakan keadaan belajar yang optimum serta mengembalikan apabila terjadi godaan dalam proses pembelajaran, Usman (2006).Keterampilan menutup pelajaran ialah aktivitas pendidikan berakhir dengan kesimpulan pembelajaran yang dilakukan pendidik, (Karwati Evis \& Donni Juni Piansa, 2014).

Dari permasalahan yang penulis amati dan lihat dilapangan ialah masih tampak seluruh pendidik yang belum optimal dalam melaksanakan pengkajian, masih ada kemampuan guru dalam menjelaskan materi pembeljaran perlu untuk tingkatkan, masih ada sebagian guru belum baik dalam bertanya perlu untuk ditingkatkan, masih ada sebagian guru dalam memberikan penguatan masih kurang, guru masih kurang optimal dalam menciptakan iklim pembelajaran yang kondusif dikelas, dan Kemampuan guru dalam menutup pelajaran masih perlu untuk ditingkatkan

Dari paparan diatas maka yang akan diteliti yaitu : 1) bagaimanakah persepsi siswa tentang Keterampilan Mengajar Guru di SMK Negeri 1 Lembah Gumanti dalam hal membuka pelajaran? 2) bagaimanakah persepsi siswa terhadap Keterampilan Mengajar Guru di SMK Negeri 1 Lembah Gumanti dalam hal menjelaskan? 3) bagaimanakah persepsi siswa terhadap Keterampilan Mengajar Guru di SMK Negeri 1 Lembah Gumanti dalam hal bertanya? 4) bagaimanakah persepsi siswa terhadap Keterampilan Mengajar Guru di SMK Negeri 1 Lembah Gumanti dalam hal memberikan penguatan? 5) bagaimanakah persepsi siswa terhadap Keterampilan Mengajar Guru di SMK Negeri 1 Lembah Gumanti dalam hal mengelola kelas? 6) bagaimanakah persepsi siswa terhadap Keterampilan Mengajar Guru di SMK Negeri 1 Lembah Gumanti dalam hal menutup pelajaran?.

\section{Metode Penelitian}

Tempat yang dilakukan oleh peneliti ialah SMK Negeri1 Lembah Gumanti. Jenis riset ialah kuantitatif. Siswa kelas XI dan XII semua jurusan yang berjumlah 515 orang siswa yang dijadikan populasnya dengan sampel 89 responden dengan menggunakan rumus slovin. Metode riset yang digunakan ialah propartional stratified random sampling. Riset ini menggunakan kuesioner dengan ukuran likert yang telah diuji validitas dan realibitasnya, rumus rata-rata yang dilakukan untuk memperoleh data hasil penelitian.

\section{Hasil dan Bahasan}

\subsection{Hasil}

Berdasarkan hasil penelitian berikut dijelaskan satu persatu menurut indikator peneliti:

Sebagai kelengkapan nilai pada umumnya mengenai tanggapan siswa tentang keterampilan mengajar guru dilihat dalam hal: a) membuka pelajaran adalah 3,84 kategori baik, hal ini diartikan bahwa kemampuan mengajar Guru di SMK N 1 Lembah Gumanti telah terlaksana dengan baik serta perlu untuk ditingkatkan. b) keterampilan menjelaskan adalah 3,84 berkategori baik, hal ini dikatakan bahwa keterampilan mengajar Guru telah terlaksana dengan baik. c) bertanya adalah 3,52 berkategori cukup baik, hal ini diartikan keterampilan mengajar guru menurut persepsi siswa berjalan dengan cukup baik 
dan perlu untuk ditingkatkan. d) memberikan penguatan adalah 3,46 berkategori cukup baik, hal ini dapat diartikan keterampilan mengajar guru di SMK Negeri Lembah Gumanti menurut persepsi siswa telah berjalan dengan cukup baik dan perlu untuk ditingkatkan. e) mengelola kelas adalah 3,73 berkategori baik, hal ini diartikan keterampilan mengajar guru di SMK Negeri 1 Lembah Gumanti menurut persepsi siswa sudah baik dan hanya perlu untuk ditingkatkan. f) mengelola kelas adalah 3,57 berkategori cukup baik, hal ini dapat diartikan bahwa keterampilan mengajar guru di SMK N 1 Lembah Gumanti menurut persepsi siswa telah berjalan dengan cukup baik dan perlu untuk ditingkatkan lagi.

\subsection{Pembahasan}

Berdasarkan hasil dari penelitian tanggapan siswa tentang keterampilan mengajar guru di SMK N 1 Lembah Gumanti dilihat dalam hal membuka pelajaran dan menjelaskan dengan rata-rata sama yaitu baik 3,84, mengelola kelas baik dengan rata-rata 3,73, menutup pelajaran pada taraf cukup baik dengn nilai 3,57 , bertanya pada taraf cukup baik dngan nilai 3,52, sedangkan memberikan penguatan pada taraf cukup baik dengn nilai 3,46 .

a. Keterampilan membuka pelajaran

Dari pengolahan hasil data penelitian menunjukkan, tanggapan siswa terhadap keterampilan mengajar guru di SMK Negeri 1 lembah gumanti dilihat dalam hal membuka pelajaran mendapatkan rata-rata 3,84 ber kategori baik dengan 10 item pernyataan. Dilihat dari segi membuka pelajaran yang tertinggi yaitu terdapat pada item penyataan "Guru mengucapkan salam ketika masuk kedalam kelas" dengan skor rata-rata 4,43. Berarti telah dilakukan dengan baik. Sedangkan item yang terendah pada pernyataan "Guru mengadakan pre test sebelum memulai pelajaran" dengan skor rata-rata 3,33.. Artinya dilihat dari segi membuka pelajaran keterampilan mengajar guru di SMK Negeri 1 Lembah Gumanti sudah terlaksana dengan baik.

b. Keterampilan menjelaskan

Dari pengolahan hasil data penelitian menunjukkan, tanggapan siswa terhadap keterampilan mengajar guru di SMK Negeri 1 lembah gumanti dilihat dalam hal menjelaskan mendapatkan rata-rata 3,84 ber kategori baik dengan 10 item pernyataan. Dilihat dari segi menjelaskan tertinggi yaitu terdapat pada item penyataan "Pada saat belajar di dalam kelas guru menjelaskan materi dengan baik"dengan skor rata-rata 4,08. Berarti telah dilakukan dengan baik. Sedangkan item yang terendah yaitu "Guru menyampaikan materi pembelajaran dengan bahasa buku" dengan skor rata-rata 3,37. Artinya dilihat dari segi menjelaskan pada keterampilan mengajar guru di SMK Negeri 1 Lembah Gumanti sudah terlaksana dengan baik.

c. Keterampilan bertanya

Dari pengolahan hasil data penelitian menunjukkan, tanggapan siswa terhadap keterampilan mengajar guru di SMK Negeri 1 lembah gumanti dilihat dari bertanya mendapatkan rata-rata 3,52 yaitu berkategori cukup baik dengan 10 item pernyataan. Dilihat dari segi bertanya yang tertinggi yaitu terdapat pada item penyataan "Guru mengajukan pertanyaan dengan bahasa yang mudah"dngan nilai 3,83 . Padahal item sedikit dalam bertanya yaitu "Guru memberikan pertanyaan kepada siswa secara merata" dengan skor rata-rata 3,22. Artinya dilihat dari segi menjelaskan keterampilan mengajar guru di SMK Negeri 1 Lembah Gumanti sudah terlaksana dengan cukup baik.

d. Keterampilan memberikan penguatan

Dari pengolahan hasil data riset menunjukkan, tanggapan siswa terhadap keterampilan mengajar guru di SMK Negeri 1 lembah gumanti dilihat dalam hal memberikan penguatan mendapatkan ratarata 3,46 yaitu ber kategori cukup baik dengan 9 item pernyataan. Dilihat dari segi memberikan penguatan yang tertinggi yaitu pada item penyataan "Guru mendekati siswa yang sedang praktik dan melihat siswa sedang bekerja"dengan skor rata-rata 3,94. Sedangkan item terendah dalam memberikan penguatan yaitu "pendidik menghadiahkan pemberian untuk murid"nilai ulangannya bagus" dengan skor rata-rata 2,39. Artinya dilihat dari segi menjelaskan keterampilan mengajar guru di SMK Negeri 1 Lembah Gumanti sudah terlaksana dengan cukup baik.

e. Keterampilan mengelola kelas

Dari pengolahan hasil data riset menunjukkan, tanggapan siswa terhadap keterampilan mengajar guru di SMK Negeri 1 lembah gumanti dilihat dari mengelola kelas mendapatkan rata-rata 3,73yaitu berkategori baik dengan 8 item pernyataan. Dilihat dari segi memberikan penguatan tertinggi yaitu terdapat pada item penyataan "Guru meminta siswa untuk menunjukkan hasil pekerjaannya"dengan skor rata-rata 4,08. Sedangkan item yang terendah pada pernyataan "Guru membagi perhatian kepada siswa" dengan skor rata-rata 3,61. Artinya dilihat dari segi menjelaskan keterampilan mengajar guru di SMK Negeri 1 Lembah Gumanti sudah terlaksana dengan baik.

f. Keterampilan menutup pelajaran 
Dari pengolahan hasil data riset menunjukkan, tanggapan siswa terhadap keterampilan mengajar guru di SMK Negeri 1 lembah gumanti dilihat dalam hal menutup pelajaran mendapatkan rata-rata 3,57 yaitu berkategori cukup baik dengan 8 item pernyataan. Dilihat dari segi menutup pelajaran yang tertinggi yaitu terdapat pada item penyataan "Kegiatan Guru menyampaikan indikator materi selanjutnya"dengan skor rata-rata 4,02. Sedangkan item yang terendah ialah "Guru memberikan soal tertulis terkait materi yang telah dipelajari" dengan skor rata-rata 3,1. Artinya dilihat dari segi menjelaskan pada kemampuan membimbing guru di SMK N 1 Lembah Gumanti sudah terlaksana dengan cukup baik.

\section{Kesimpulan}

Kesimpulan hasil dari penelitian mengenai Persepsi Siswa terhadap Keterampilan Mengajar Guru di SMK N 1 Lmbah Gumanti dilihat dalam hal keterampilan membuka pelajaran kategori baik dngan nilai 3,84. Keterampilan menjelaskan kategori baik dengan nilai 3,84. Keterampilan bertanya kategori agak baik dngan nilai 3,52. Keterampilan memberikan penguatan kategori agak baik dngan nilai 3,46. Keterampilan mengelola kelas kategori bagus dengn nilai 3,73. Keterampilan menutup pelajaran kategori agak baik dengn nilai 3,57. Menurut umum tanggapan murid tentang keterampilan mengajar guru di SMK Negeri 1 Lembah Gumanti sudah kategori bagus dngan nilai 3,66.

Dengan demikian kesimpulan diatas, tentang tanggapan murid tentang keterampilan mengajar pendidik di SMK N 1 lembah gumanti bisa dikatakan sudah terlaksana dengan baik sinkron dengn kuesioner yg sudah diisi murid untuk itu masih perlunya adanya peningkatan dari kepala sekola dan guru dalam menunjang nya peningkatan keterampilan mengajar guru dalam mencapai kategori sangat baik agar keterampilan yang dimiliki oleh guru dapat terlaksana dengan optimal.

\section{Daftar Rujukan}

Asril, zainal. (2011). Micro Teaching disertai dengan pengalaman lapangan. Rajawali Pers.

Karwati Evis \& Donni Juni Piansa. (2014). Manajemen Kelas (Calssroom Management). Alfabeta.

Mulyasa. (2011). Menjadi Guru Profesional menciptakan Pelajaran Kreatif \& Menyenangkan. PT Remaja Rosdakarya.

Syaripuddin. (2011). Mengajar di Abad 21 (Keterampilan Dasar Mengajar dan Pendekatan Pembelajaran k13). Uwais inspirasi indonesia.

Usman, U. (2006). menjadi guru profesional. PT Remaja Rosdakarya. 